\title{
Slaapapneu: iets om wakker van te liggen?
}

\section{INLEIDING}

Als kortdurende periodes van nachtelijke apnoe het slaapritme ontregelen, spreken we van een slaapverstorende ademhaling of slaapapneu. Als hierbij tevens klachten optreden van concentratiestoornissen of moeheid overdag, dan spreken we van een slaapapneusyndroom. Dit kan een obstructieve (OSAS) of centrale (CSAS) oorzaak hebben en wordt in verband gebracht met een verhoogd cardiovasculair risico. Slaapapneu wordt op arbitraire gronden onderverdeeld aan de hand van het aantal onderbrekingen in de ademhaling per uur in gering (5-15 onderbrekingen), matig (15-30 onderbrekingen) en ernstig (meer dan 30 onderbrekingen per uur). Voor het stellen van de diagnose maken we onder andere gebruik van polysomnografisch onderzoek. Sinds enkele jaren worden nieuwe, meer sensitieve, registratietechnieken gebruikt. Hiermee is het niet alleen mogelijk om beter vast te stellen of er sprake is van een slaapverstorende ademhaling, maar is ook de ernst beter te bepalen. Het is onduidelijk wat het gevolg is van deze verbetering in de diagnostiek voor de prevalentie van patiënten met een slaapapneu of het slaapapneusyndroom, en de relatie met mogelijke gezondheidsschade.

\section{ONDERZOEK}

Het HypnoLaus-onderzoek is een onderzoek naar de prevalentie van slaapverstorende ademhaling bij een random sample uit de bevolking van Lausanne (Zwitserland) van 40 jaar en ouder. De onderzoekers nodigden ruim 3000 personen uit om deel te nemen aan een slaaponderzoek: $71 \%$ accepteerde de uitnodiging, de gemiddelde leeftijd was 57 jaar. Naast polysomnografisch onderzoek inventariseerden zij klachten en onderzochten zij bloeddruk, BMI, alcoholgebruik, lipidenspectrum, diabetes mellitus en depressie. Slaapapneu blijkt als een continuüm in de gehele bevolking voor te komen: van gering tot ernstig, al dan niet gepaard gaand met klachten van slaperigheid of vermoeidheid overdag. Bij ongeveer $84 \%$ van de mannen en $61 \%$ van de vrouwen is er sprake van 5 of meer apneu-episodes per uur. Ongeveer $8 \%$ van de mannen en $5 \%$ van de vrouwen heeft naast 5 of meer apneus per uur ook klachten, zodat er gesproken kan worden van een slaapapneusyndroom. Slaapverstorende ademhaling neemt toe naarmate de deelnemers ouder worden, het slaapapneusyndroom is evenredig verdeeld over alle leeftijdsgroepen. De prevalentie neemt ook toe bij obesitas en als er sprake is van snurken. Er kan geen verband aangetoond worden tussen een slaapverstorende ademhaling en de aanwezigheid van slaperigheid overdag. Bij deelnemers met een score van 20 of meer apneu-episodes per uur was er na correctie voor gebruikelijke cardiovasculaire risicofactoren een onafhankelijke associatie met hypertensie, diabetes type 2 en depressie.

\section{INTERPRETATIE}

Op grond van dit onderzoek lijkt slaapapneu vaker voor te komen dan tot nu toe werd aangenomen. De NHG-Standaard Slaapproblemen en slaapmiddelen gaat uit van de prevalentiecijfers voor de Nederlandse situatie uit onderzoek van Knuistingh-Neven uit 1996. De prevalentie van het slaapapneusyndroom bij mannen met 5 of meer apnoe-episodes per uur én klachten overdag wordt daarin geschat op ten minste $0,45 \%$. Mogelijk is er bij de prevalentieschatting in het HypnoLaus-onderzoek sprake van overschatting. Ongeveer $30 \%$ van de oorspronkelijke steekproef heeft geen gehoor gegeven aan de oproep om aan het onderzoek deel te nemen. Het is goed voorstelbaar dat personen die klachten hebben op het gebied van slaap en snurken eerder geneigd zijn zich voor het onderzoek op te geven en er dus sprake is van een selectiebias. Het stellen van de diagnose slaapapneu kan ingrijpende gevolgen hebben voor de patiënt. Omdat lichtere vormen van nachtelijk apneu veelvuldig voorkomen en de samenhang met cardiovasculaire ziekte en klachten alleen bij de ernstige vormen van slaapapneu lijken op te treden, stellen Heinzer et al. voor om bij het stellen van de diagnose niet van een specifiek afkappunt uit te gaan, maar van een continu spectrum. Interventies worden dan afhankelijk gesteld van eventuele klachten, cardiovasculaire comorbiditeit en het aantal apneu-episodes per uur. Het moment om over te gaan op meer invasieve interventies, zoals het ontzeggen van de rijbevoegdheid, CPAP of maxillomandibulaire chirurgie, lijkt momenteel nog vrij willekeurig. Zolang er nog onvoldoende klinisch onderzoek is gedaan om hoogrisicogroepen te identificeren die mogelijk baat hebben bij meer agressieve interventies en slaapapneu meer regel dan uitzondering is, moeten de resultaten van polysomnografisch onderzoek kritisch geïnterpreteerd worden.

\section{LITERATUUR}

1 Heinzer R, Vat S, Marques-Vidal P, Marti-Soler H, Andries D, Tobback N, et al. Prevalence of sleep-disordered breathing in the general population: the HypnoLaus study. Lancet Respir Med 2015;3:310-18.

2 NHG-Werkgroep Slaapproblemen en slaapmiddelen. Huisarts Wet 2014;57:352-61. 